African territories. In addition to an annual week-end conference of members, branch meetings are held from time to time at Kumasi and Cape Coast. The papers read at the inaugural meeting in January I9S 2 have been published in Volume I, part I, of the Society's transactions and include papers by Professor Varley on 'Castles and Forts of the Gold Coast' (illustrated by a number of excellent photographs), by Mr. Attafua on 'Traditional History', by Mr. Akita on 'Documentary material available for historical research in the Gold Coast', and by Dr. J. D. Fage, President of the Society, on 'Some general considerations relevant to historical research in the Gold Coast'. Dr Fage points out the urgent need for work to be done 'in the recording and elucidating of oral traditions, in the collection, preservation and interpretation of documentary material, and in research into the social and economic life of the country's past'. Until this work is done, no real understanding of Gold Coast history can be achieved.

\title{
Institut International des Civilisations Différentes (INCIDI)
}

LA $28^{\circ}$ session de l'INCIDI, tenu du 7 au Io septembre I953 à la Haye, fut consacrée à l'étude du relèvement rural dans les pays tropicaux et sub-tropicaux. La réunion avait été préparéeppar la distribution préalable à tous les participants de vingt-huit rapports spéciaux exposant les programmes et plans en cours ou projetés dans les territoires d'Afrique, d'Asie, d'Amérique du Sud et Centrale, rédigés par des experts de 16 pays, d'un rapport introductif préparé par Sir Bernard Binns de la F.A.O., et de trois rapports généraux. Les échanges de vues, auxquels participèrent plus de 80 personnalités de nombreux pays, furent immédiatement centrés sur les projets de conclusions contenus dans chacun des rapports généraux. Le travail poursuivi en séances plénières présidées par le Dr. P. J. Idenburg aboutit à l'adoption d'un certain nombre de résolutions concernant: (I) L'économie rurale, y compris la conservation des ressources naturelles, les obligations internationales dans l'assistance au développement, coordination des programmes de développement, la politique agricole nationale, les services agricoles; (2) Vie sociale rurale; (3) Politique et droit agraires; (4) Considérations sur le droit foncier. En outre quelques conclusions d'ordre général ont été formulées touchant l'insuffisance des études à ce sujet, la nécessité de tenir compte du facteur humain, de comprendre la mentalité des peuples intéressés et d'achever l'adhésion psychologique et la collaboration effective des populations dans tous les plans de développement rural.

\section{Agricultural Education in Uganda}

Ir is proposed to establish a Faculty of Agriculture at Makerere College, the University College of East Africa. The plan includes provision for teaching staff, a Faculty building with a laboratory and a university farm. A 340-acre holding ten miles from Makerere, as well as a herd of 60 Zebu-Ankoli cattle, have already been purchased for the university farm and a contour survey of the land has been started. The courses of instruction offered will be planned to enable students to enter for the London B.Sc. degree in agriculture.

As a complement to the Faculty of Agriculture, the Government of Uganda proposes to set up two Agticultural Institutes, one east and one west of the Nile, to provide practical training in modern methods of agriculture. These Institutes will be under the control of the Agricultural department and will include courses for departmental agricultural students as well as for farmers and cultivators. It is also intended to establish eight district Institutes providing less advanced courses for cultivators. 